\title{
Mutational landscape of gingivo-buccal oral cancer: new cancer genes and molecular subgroups identified
}

\author{
Partha P Majumder
}

From International Conference on Human Genetics and 39th Annual Meeting of the Indian Society of Human Genetics (ISHG)

Ahmadabad, India. 23-25 January 2013

Gingivo-buccal oral cancer (GBOC), an anatomical and clinical sub-type of head and neck squamous cell carcinoma (HNSCC), is prevalent in regions where tobaccochewing is common. Exome sequencing and other data on 50 GBOC tumor/normal DNA pairs revealed (a) significantly and recurrently mutated genes that are (i) specific (USP9X, MLL4, ARID2, UNC13C and TRPM3), and (ii) shared with HNSCC (e.g., TP53, CDKN2A, PIK3CA, HRAS, NOTCH1); (b) new genes with recurrent amplifications (e.g., DROSHA, YAP1) or homozygous deletions (e.g., $D D X 3 X)$; (c) existence of molecular sub-types, with distinctive mutational profiles; (d) high proportion of $\mathrm{C}>\mathrm{G}$ transversions, not noted earlier in HNSCC, among tobacco users with high numbers of mutations; and, (e) enrichment of alterations of pathways specific to GBOC, including Neurotrophin signaling, Wnt signaling, dorsoventral axis formation and axon guidance. Recurrently mutated genes were validated on an independent set of 30 GBOC patients. These findings open new vistas for biological characterization and exploration of therapies.

Submit your next manuscript to BioMed Central and take full advantage of:

- Convenient online submission

- Thorough peer review

- No space constraints or color figure charges

- Immediate publication on acceptance

- Inclusion in PubMed, CAS, Scopus and Google Scholar

- Research which is freely available for redistribution
() Biomed Central 